Fluid Phase Equilibria

Accepted version of the manuscript: https://doi.org/10.1016/j.fluid.2018.11.010

\title{
Phase Equilibria of 1-hexyl-3-methylimidazolium acetate with water and oil
}

\author{
R. Corchero, I. Rodríguez-Escontrela, O. Rodríguez, A. Soto* \\ Department of Chemical Engineering, Universidade de Santiago de Compostela, E- \\ 15782 Santiago de Compostela, Spain \\ *ana.soto@usc.es
}

\begin{abstract}
Ionic liquids have increased the possibilities of Enhanced Oil Recovery (EOR) with surfactants. However, results obtained with only one of these salts as surfactant are not particularly promising. Best results are obtained with blends of these salts or blends with traditional surfactants. This work aims to break new ground regarding the role of ionic liquids in this application. Many traditional surfactants in EOR fail because they are not sufficiently soluble at optimal salinity in water. The possibilities of design of ionic liquids must also be considered to use them as co-surfactants in optimal formulations for oil recovery. In this work, the phase behaviour of the ionic liquid 1hexyl-3-methylimidazolium acetate with water and different model oils (n-octane, cyclohexane and toluene) was determined at $298.15 \mathrm{~K}$ and $323.15 \mathrm{~K}$. The complete miscibility of the ionic liquid with water and its low miscibility with the different oils, point to the use of 1-hexyl-3-methylimidazolium acetate as co-surfactant with surfactants with high oil solubilising capacity.
\end{abstract}

Keywords: Ionic Liquid; Water; Oil; Equilibrium; EOR.

\section{Introduction}

In oil recovery, at the end of water flooding, the residual oil is in the form of immobile globules distributed through the pores of the rocks. An ultra-low interfacial tension between crude oil and aqueous phases is required to allow the oil mobilisation and enhance oil recovery. This can be achieved in the presence of a suitable surface active 
agent. Surfactant Enhanced Oil Recovery (EOR) is based on a multicomponent multiphase system, generated by the injection of an optimal formulation, whose displacement is complicated by factors of phase behaviour, dispersion, and adsorption.

Surfactant solution phase behaviour is strongly affected by the presence of salt in the reservoir. At a low salinity, the surfactant is soluble in the aqueous phase and some oil is solubilised in the core of the micelles. A lower-phase microemulsion is formed in equilibrium with an excess oil phase essentially free of surfactant. At high salinity, the system separates in an oily upper-phase microemulsion in equilibrium with an excess water phase. At some intermediate salinity, the system forms three phases; an excess oil phase, a middle-phase microemulsion where the surfactant solubilises equivalent weight of water and oil, and an excess water phase [1]. This salinity is considered optimal because it produces the lowest interfacial tension.

Many surfactants that show ultra-low interfacial tension and excellent microemulsion phase behaviour with crude oils are not sufficiently soluble at optimal salinity to give clear, stable, aqueous solutions [2]. Poor surfactant solubility may result in very high surfactant retention in the well. The use of hydrophilic co-solvents or co-surfactants helps to dissolve the surfactant in the brine and to reduce surfactant retention. Moreover, the use of these compounds could be a key factor for promoting good phase behaviour during a surfactant flooding operation.

One of the main advantages of Ionic liquids (ILs) is that they can be tailored to have a specific property or to be used in a specific application [3]. With this in mind, some researchers have proposed the use of surface active ILs as surfactants for EOR [4-7]. Bera and Belhaj [4] present a state of the art-review of the use of ILs as alternatives to surfactants in EOR. Several ILs have been found active in reducing interfacial tension as well as changing the reservoir rock surface wettability, however up to now an ultralow interfacial tension $\left(\sim 10^{-3} \mathrm{mN} / \mathrm{m}\right)$ has not been achieved using a single IL. Recently, some works propose the use of blends of ILs and traditional surfactants [8,9]. Rodríguez-Escontrela et al. [8] propose the use of a blend $\operatorname{IOS}_{15-58 / 1-d o d e c y l-3-}$ methylimidazolium bromide (mass ratio $=8 / 2$ ). A low equilibrium interfacial tension of $\sim 2 \cdot 10^{-3} \mathrm{mN} / \mathrm{m}$ was obtained between $n$-octane and seawater. Jia et al. [9] propose the blend n-dodecyl-n-methylpyrrolidinium bromide/SDS (molar ratio of 1:2.5) obtaining 
an interfacial tension of $\sim 4 \times 10^{-3} \mathrm{mN} / \mathrm{m}$ between model oil ( $n$-decane or toluene) and water.

The work on ILs as co-surfactants in combination with traditional surfactants for EOR applications has not practically started. Only one recent work was found in literature [10] where these salts are used with traditional surfactants to decrease surfactant adsorption onto crushed core samples. The use of these salts as co-surfactants in EOR formulations could improve the solubility of the surfactant in the injectable aqueous solution, avoid surfactant retention and increase oil recovery. They also could allow slugs to be tailored for high salinity and temperature. Moreover, as ILs are salts, they could be used to modify the optimal salinity of a surfactant leading to a change in phase behaviour. For these reasons, this research should be encouraged.

As a first step in the analysis of the possibilities of using the ionic liquid 1-hexyl-3methylimidazolium acetate $([\mathrm{C}$ mim $][\mathrm{OAc}])$ as co-surfactant in EOR, in this work, the phase behaviour of the aforementioned IL with water and different model oils ( $n$-octane, cyclohexane and toluene) is determined at $298.15 \mathrm{~K}$ and $323.15 \mathrm{~K}$. Data are correlated for each ternary system and all the data sets with the Non-Random Two Liquid activity coefficient model [11]. The consistency of the binary coefficients obtained is tested according to the method of Marcilla et al. [12].

\section{Experimental}

\subsection{Chemicals}

Information about all the chemicals used in this work can be found in Table 1. Water was purified via double distillation. Several organic compounds were used to mimic different oils. $n$-Octane and toluene with nominal purities $>99.9 \mathrm{wt} \%$ and $>99.5 \mathrm{wt} \%$, respectively, were purchased from Sigma-Aldrich. Cyclohexane with a nominal purity $>99.5 \mathrm{wt} \%$ was purchased from Riedel-de Haën. All these chemicals were used as

received, with the only precaution of having molecular sieves into the bottles for drying the organic solvents.

1-Hexyl-3-methylimidazolium acetate was synthesised in our laboratory by metathesis reaction. 1-hexyl-3-methylimidazolium chloride (Sigma-Aldrich, >97\%) and potassium 
acetate (Sigma-Aldrich, 99\%) were used as reactants. They were let to react in 2propanol (Panreac, $>99.8 \%$ ) for 48 hours under stirring. A precipitate $(\mathrm{KCl})$ was removed via filtration. The volatile solvent was removed by means of a rotary evaporator. The sample was dissolved several times in cold acetone (Sigma-Aldrich, ACS reagent, $>99.5 \%$ ) and filtered until the total elimination of $\mathrm{KCl}$. After this process, no precipitation was observed upon addition of $0.1 \mathrm{M}$ aqueous solution of silver nitrate to an aqueous solution of the ionic liquid. The absence of relevant levels of impurities was verified by ${ }^{1} \mathrm{H}$ and ${ }^{13} \mathrm{C}$ nuclear magnetic resonance (NMR) spectroscopy analyses.

\subsection{Methods}

In order to check if the ionic liquid [ $\left.\mathrm{C}_{6} \mathrm{mim}\right][\mathrm{OAc}]$ had surfactant character, the surface tension of aqueous solutions of the salt was measured looking for a critical micelle concentration. The Wilhelmy plate method was used by means of a Krüss K11 tensiometer. A platinum cylinder (Krüss accessory reference PL22) was used for measurements. Temperature was kept constant with a Selecta Frigiterm-10 cryogenic thermostat. The uncertainty in the measurement of temperature is $0.05 \mathrm{~K}$. Each sample was analysed at least two times (more if the results showed deviations greater than uncertainty), with twelve consecutive measurements for each sample (the first two were systematically disregarded). The estimated uncertainty is $0.3 \mathrm{mN} / \mathrm{m}$.

To determine the experimental liquid-liquid equilibrium for the ternary systems, firstly the cloud-point method was used to obtain the solubility curves. Mixtures, with compositions inside these curves, were mixed in jacketed vessels. The mixtures were magnetically stirred for $2 \mathrm{~h}$ and then settled down for a minimum of $12 \mathrm{~h}$, at a fixed temperature maintained by means of a Selecta Ultraterm 200 thermostatic bath. Preliminary tests were carried out to ensure that these times were enough to ensure equilibrium. Samples were withdrawn and analysed by gas chromatography. A HewlettPackard HP6890 series GC was used with a split injector, a TCD detector, and a HPFFAP $(25 \mathrm{~m} \times 0.2 \mathrm{~mm} \times 0.33 \mu \mathrm{m})$ capillary column. An empty pre-column was used to prevent ionic liquid not retained in the liner reaching the analytical column. Helium was used as the mobile phase and the injection volume was $1 \mathrm{~mL}$ with a split ratio of 1:50. The injector and detector temperature were set to $523.15 \mathrm{~K}$ and $503.15 \mathrm{~K}$ respectively. The oven temperature program was started at $333.15 \mathrm{~K}$ ( 5 minutes for n-octane and cyclohexane systems, and 7 minutes for toluene system), followed by a temperature 
ramp at $75 \mathrm{~K} \mathrm{~min}^{-1}$ up to $473.15 \mathrm{~K}$, this temperature was kept constant for $1 \mathrm{~min} .1$ Butanol was used as diluent and 2-propanol as standard. Chromatographic analysis allowed the determination of water and oil mass fractions, following the preparation of calibration curves, and in this way the composition of the ternary mixture was calculated. The negligible IL content in the oil phase determined by chromatography was also contrasted by using ICP (optical) spectroscopy

\section{Results}

In a previous work [13], the possibility of using the ionic liquid [ $\left.\mathrm{C}_{12 \mathrm{mim}}\right][\mathrm{OAc}]$ as surfactant for EOR was analysed. It was found that this surfactant could drastically reduce the interfacial tension water/oil, however the values obtained for this property were found far from the ultra-low values required in EOR. Thus, the idea of using these ionic liquids as co-surfactants rather than surfactants came up. Blesic et al. [14] showed that $\left[\mathrm{C}_{\mathrm{n}} \mathrm{mim}\right] \mathrm{Cl}$ ionic liquids with $\mathrm{n}>8$ form micellar aggregates in water. For $\mathrm{n}<8$ these salts do not show an interfacial tension plateau which indicates that the hydrophobicity is not sufficient to build up micelles in these cases. A similar behaviour was expected for $\left[\mathrm{C}_{\mathrm{n}} \mathrm{mim}\right][\mathrm{OAc}]$ ionic liquids.

In this work therefore, since the use of 1-methyl-3-alkylimidazolium acetate ionic liquid is proposed as co-surfactant, an alkyl chain length six carbon units long was selected. To confirm that $\left[\mathrm{C}_{6} \mathrm{mim}\right][\mathrm{OAc}]$ does not have surfactant character, the surface tension of aqueous solutions at several concentrations of the ionic liquid was represented (Figure 1). As a plateau in surface tension is not observed, as expected, the ionic liquid is not a surface active agent. The values of the surface tension are presented in Table 2.

Tables 3 to 8 show the liquid-liquid equilibrium of the ternary systems water + [C6mim][OAc] + hydrocarbon ( $n$-octane, toluene and cyclohexane) at $298.15 \mathrm{~K}$ and $323.15 \mathrm{~K}$ and $0.1 \mathrm{MPa}$. The water $+[\mathrm{C} 6 \mathrm{mim}][\mathrm{OAc}]$ pair is totally miscible at both temperatures. Within uncertainties of analysis the pair water + hydrocarbon is totally immiscible, what is in good agreement with previous studies that show mutual solubilities of these compounds in the order of ppm [15]. Also the solubility of $\left[\mathrm{C}_{6} \mathrm{mim}\right][\mathrm{OAc}]$ in the hydrocarbons is found to be negligible. This is consistent with studies carried out by Song et al. [16] who measured solubilities of the ionic liquid in 
$n$-octane, toluene and cyclohexane at $298.15 \mathrm{~K}$, obtaining values of 99, 643 and 124 ppm, respectively. Regarding the ternary systems, they show biphasic regions where the upper phase consists of only organic solvent.

Tables 3 and 4 show the liquid-liquid equilibrium of the ternary system water + [C6mim] $[\mathrm{OAc}]+\mathrm{n}$-octane at $298.15 \mathrm{~K}$ and $323.15 \mathrm{~K}$, respectively. Figures 2 and 3 show that these systems can be classified as Treybal type II due to the partial miscibility of the water $+n$-octane and $\left[\mathrm{C}_{6} \mathrm{mim}\right][\mathrm{OAc}]+n$-octane pairs. Increasing the temperature, the solubility of n-octane in the ionic liquid slightly increases. However practically all the ternary mixtures, at both temperatures, form biphasic systems consisting of one pure oil phase and the other an aqueous solution of the ionic liquid.

Data for the ternary system of ionic liquid with water and toluene are presented in Tables 5 and 6 and shown in Figures 4 and 5. Phase diagrams for this oil are also Treybal type II. However, the interactions between the aromatic ring of the imidazolium and toluene lead to a higher solubility of the toluene than $n$-octane in the ionic liquid. A solubility of toluene in the ionic liquid of 0.349 (mass fraction) is found at $298.15 \mathrm{~K}$ that increases up to 0.357 at $323.15 \mathrm{~K}$.

Phase diagrams for water $+\left[\mathrm{C}_{6} \mathrm{mim}\right][\mathrm{OAc}]+$ cyclohexane ternary system at $298.15 \mathrm{~K}$ and $323.15 \mathrm{~K}$ and $0.1 \mathrm{MPa}$ are shown in Figures 6 and 7, respectively. Mass compositions of the ends of the tie-lines are shown in Tables 7 and 8 . As in the case of $n$-octane, the phase diagram can be classified as a Treybal Type II system, and due to a low solubility of the cycloalkane in the ionic liquid, the tie-lines cover up almost the whole ternary diagram.

\section{Data treatment}

\subsection{Data correlation}

Mole fractions are correlated using the NRTL [11] activity coefficient model. The value of the non-randomness parameter $\alpha$ is pre-fixed at $0.1,0.2$ and 0.3 , and the value that achieves the minimum deviations from experimental data is selected.

Following the method of Sprensen and Arlt [17], two objective functions are used in the correlation. First, $F_{a}$, which does not require any previous guess for parameters, and 
after convergence these parameters are used in the second function, $F_{b}$, to minimise deviations in mole fractions:

$F_{a}=\sum_{k} \sum_{i}\left[\left(a_{i k}^{I}-a_{i k}^{I I}\right) /\left(a_{i k}^{I}+a_{i k}^{I I}\right)\right]^{2}+Q \sum_{n} P_{n}^{2}$

$F_{b}=\sum_{k} \min \sum_{i} \sum_{j}\left(x_{i j k}-\hat{x}_{i j k}\right)^{2}+Q \sum_{n} P_{n}^{2}$

a: activity; $x$ : mole fraction; $P_{n}$ : adjustable parameters; $Q$ : penalty term, $10^{-6}$ in Eq (1) and $10^{-10}$ in Eq. (2); $i$ : components; $j$ : phases (I, II); $k$ tie-lines; ${ }^{\wedge}$ means calculated.

Deviations of the correlations are determined according to:

$F=100\left[\sum_{k} \min \sum_{i} \sum_{j} \frac{\left(x_{i j k}-\hat{x}_{i j k}\right)^{2}}{6 M}\right]^{0.5}$

$M$ : number of tie-lines.

NRTL parameters and $F$ deviations for all the ternary systems ( $\alpha$ optimised) at 298.15 $\mathrm{K}$ and $323.15 \mathrm{~K}$ are presented in Tables 9-11 for n-octane, toluene, and cyclohexane, respectively. These tables also show the results of the simultaneous correlation at both temperatures. Results (also shown graphically in Figures 2 to 7) demonstrate that this activity coefficient model adequately correlate these equilibria. When the simultaneous correlation at both temperatures is carried out, higher deviations are found, particularly noticeable in the case of the system with toluene. As these systems share the binary system water $+\left[\mathrm{C}_{6} \mathrm{mim}\right][\mathrm{OAc}]$ and the correlation parameters of this system should be common, a simultaneous correlation of all the systems at both temperatures is carried out and results are shown in Table 12. A deviation in compositions of 0.017 is found in this case.

\subsection{Consistency of correlation parameters}

The method and software proposed by Marcilla et al. [12] is used to test the consistency of the NRTL correlation parameters for each ternary system. The minor common tangent criterion is the necessary and sufficient condition for solving phase equilibria, thus the topology analysis of the Gibbs energy curve of the mixture (GM) allows the consistency of correlation parameters to be easily checked. Figure 8 show the results obtained with the software presented in the above mentioned paper for all the ternary systems at $298.15 \mathrm{~K}$. 
For the water (1) $+\left[\mathrm{C}_{6}\right.$ mim $][\mathrm{OAc}](2)$ miscible binary subsystem, no common tangent line to the Gibbs energy curve of the mixture (GM) exists. For [ $\left.\mathrm{C}_{6} \mathrm{mim}\right][\mathrm{OAc}](2)+\mathrm{n}$ octane/toluene/cyclohexane (3) binary subsystems that are partially miscible, one minor common tangent line that corresponds with the calculated LLE tie-line exists. Figure 8 confirms the consistency between the calculated tie-lines and the GM surface obtained with the parameters shown in Tables 9 to 11 .

Miscible (L) and partially miscible (LL) regions and boundary were also calculated (Figure 7), using the NRTL model, as a function of the dimensionless conjugated binary parameters [18], and the results are in agreement with experimental evidence.

\section{Conclusions}

The ionic liquid [C6mim][OAc] does not possess surfactant character. As a preliminary study on the possibility of using this salt as co-surfactant in surfactant or micellar flooding EOR processes, the behaviour of this ionic liquid with water and different kinds of oils was studied.

The water $+\left[\mathrm{C}_{6} \mathrm{mim}\right][\mathrm{OAc}]$ pair is completely miscible which is an important advantage focusing on the preparation of optimal formulations for EOR. The ionic liquid could be the base to prepare clear aqueous solutions of surfactants, thus avoiding the problems associated with alcohols that are usually selected as co-surfactants.

$\left[\mathrm{C}_{6} \mathrm{mim}\right][\mathrm{OAc}]$ is able to solubilise a certain quantity of toluene but its miscibility with $n$-octane and cyclohexane is very limited. With a small quantity of water added, the system splits into two phases. Phase diagrams obtained point to the use of this ionic liquid with a surfactant with high capacity to solubilise oil.

As equilibrium data can be useful for different applications, the ternary liquid-liquid equilibria obtained were correlated with the NRTL equation obtaining low deviations. Moving from the correlation of one ternary system to the simultaneous correlation of all data sets allowed the representation of all phase diagrams with a single set of parameters. The penalty of such correlation is an increase on the deviation from experimental concentrations up to $1.7 \mathrm{~mol} \%$.

\section{Acknowledgements}


The authors acknowledge the Ministry of Economy and Competitiveness (Spain) for financial support throughout project CTQ2015-68496-P (including European Regional Development Fund advanced funding).

\section{References}

[1] J.J. Sheng. Enhanced Oil Recovery. Field Case Studies. Elsevier, Amsterdam, 2013.

[2] V. Sahni, R.M. Dean, C. Britton, D.H. Kim, U Weerasooriya, G.A. Pope. SPE130007-MS (2010).

[3] K.R. Seddon. Tech. Biotechnol. 68 (1997) 351-356.

[4] A. Bera, H. Belhaj. J.Mol. Liq. 224 (2016) 177-188.

[5] J.F.B. Pereira, R. Costa, N. Foios, J.A.P. Coutinho. Fuel 134 (2014) 196-200.

[6] I. Rodríguez-Escontrela, I. Rodríguez-Palmeiro, O. Rodríguez, A. Arce and A. Soto. Fluid Phase Equilibr. 417 (2016) 87-95.

[7] S.K. Nandwani, N.I. Malek, V.N. Lad, M. Chakraborty, S. Gupta. Colloids Surf. A 516 (2017) 383-393.

[8] I. Rodriguez-Escontrela, M.C. Puerto, C.A. Miller, A. Soto, A. J. Colloid Int. Sci.504 (2017) 404-416.

[9] H. Jia, X. Leng, M. Hu, Y.L. Song, H.Y. Wu, P. Lian, Y.P. Liang, Y.G. Zhu, J.P. Liu, H.T. Zhou. Colloid Suface A 529 (2017) 621-627.

[10] A.S. Hanamertani, R.M. Pilus, A.K. Idris, S. Irawan, I.M. Tan. J. Petrol. Sci. Eng. 162 (2018) 480-490.

[11] H. Renon, J.M. Prausnitz, AIChE J. 14 (1968) 135-144.

[12] A. Marcilla, J.A. Reyes-Labarta, M.M. Olaya. Fluid Phase Equilibr. 433 (2017) 243-252.

[13] I. Rodríguez-Palmeiro, I. Rodríguez-Escontrela, O. Rodríguez, A. Arce, A. Soto. RSC Adv. 5 (2015) 37392-37398

[14] M. Blesic, M.H. Marques, N.V. Plechkova, K.R. Seddon, L.P.N. Rebelo, A. Lopes. Green Chem. 9 (2007) 481-490.

[15] J. Polak, B.C.Y. Lu. Can. J. Chem. 51 (1973) 4018-4023.

[16] Z. song, Q. Zeng, J. Zhang, H. Cheng, L. Chen, Z. Qj. J. Mol. Liq. 224 (2016) 544550. 
[17] J. M. Sørensen, W. Arlt. Liquid-Liquid Equilibrium Data Collection, DECHEMA Chemistry Data Series, Frankfurt, 1980.

[18] A. Marcilla-Gomis, J.A. Reyes-Labarta, M.D. Serrano-Cayuelas, M.M. OlayaLópez. The Open Thermodyn. J. 5 (2011) 48-62. 
Table 1. Specifications for pure components used in this work.

\begin{tabular}{|c|c|c|c|c|c|c|}
\hline Chemical name & Source & Purification method & $\begin{array}{l}\text { Purity/mass } \\
\text { fraction }\end{array}$ & $\begin{array}{l}\text { Water content/ } \\
\text { ppm }\end{array}$ & $\begin{array}{c}\text { Chloride } \\
\text { content/ppm }\end{array}$ & Analysis method \\
\hline $\begin{array}{c}\text { water } \\
\text { CAS no.: } 7732-18-5\end{array}$ & - & Distillation & - & - & - & - \\
\hline $\begin{array}{c}n \text {-octane } \\
\text { CAS no.: 111-65-9 }\end{array}$ & $\begin{array}{l}\text { Sigma- } \\
\text { Aldrich }\end{array}$ & - & $>99.9$ & $<13$ & - & GC, KF \\
\hline $\begin{array}{c}\text { cyclohexane } \\
\text { CAS no.: } 110-82-7\end{array}$ & $\begin{array}{l}\text { Riedel- } \\
\text { deHaën }\end{array}$ & - & $>99.5$ & $<11$ & - & $\mathrm{GC}, \mathrm{KF}$ \\
\hline $\begin{array}{c}\text { Toluene } \\
\text { CAS no.: } 108-88-3\end{array}$ & $\begin{array}{l}\text { Sigma- } \\
\text { Aldrich }\end{array}$ & - & $>99.5$ & $<196$ & - & $\mathrm{GC}, \mathrm{KF}$ \\
\hline $\begin{array}{c}{\left[\mathrm{C}_{6} \mathrm{mim}\right][\mathrm{OAc}]} \\
\text { CAS no.: } 888320-05-6\end{array}$ & $\begin{array}{l}\text { Home } \\
\text { made }\end{array}$ & $\begin{array}{l}\text { Rotary evaporator } \\
\text { and vacuum pump }\end{array}$ & $>99.0$ & $<950$ & $<1470$ & NMR, KF, IC \\
\hline
\end{tabular}

GC: Gas Chromatography, KF: Karl Fischer, NMR: Nuclear Magnetic Resonance, IC: Ion Chromatography 
Table 2: Surface tension as function of [ $\left.\mathrm{C}_{6} \mathrm{mim}\right][\mathrm{OAc}]$ concentration in aqueous solution at $298.15 \mathrm{~K}$ and $0.1 \mathrm{MPa}$.

\begin{tabular}{ccc}
\hline$w t \%$ & $C(\mathrm{~mol} / \mathrm{kg})$ & $r(\mathrm{mN} / \mathrm{m})$ \\
\hline 0.007 & 0.0003 & 66.55 \\
0.069 & 0.0030 & 60.77 \\
1.013 & 0.0448 & 51.97 \\
30.050 & 1.3278 & 41.00 \\
100.00 & 4.4186 & 36.00 \\
\hline
\end{tabular}

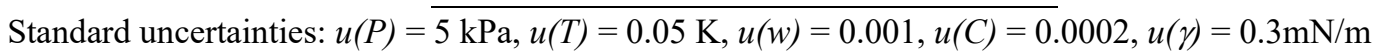


Table 3. Liquid-liquid equilibrium of the ternary system water (1) $+\left[\mathrm{C}_{6} \mathrm{mim}\right][\mathrm{OAc}](2)$ $+n$-octane (3) at $298.15 \mathrm{~K}$ and $0.1 \mathrm{MPa}$.

\begin{tabular}{|c|c|c|c|c|c|}
\hline \multicolumn{3}{|c|}{ Upper phase } & \multicolumn{3}{|c|}{ Lower phase } \\
\hline$w_{1}$ & $w_{2}$ & $w_{3}$ & $w_{1}$ & $w_{2}$ & $w_{3}$ \\
\hline 0.000 & 0.000 & 1.000 & 1.000 & 0.000 & 0.000 \\
\hline 0.000 & 0.000 & 1.000 & 0.902 & 0.098 & 0.000 \\
\hline 0.000 & 0.000 & 1.000 & 0.703 & 0.297 & 0.000 \\
\hline 0.000 & 0.000 & 1.000 & 0.509 & 0.491 & 0.000 \\
\hline 0.000 & 0.000 & 1.000 & 0.323 & 0.677 & 0.000 \\
\hline 0.000 & 0.000 & 1.000 & 0.214 & 0.775 & 0.011 \\
\hline 0.000 & 0.000 & 1.000 & 0.142 & 0.844 & 0.014 \\
\hline 0.000 & 0.000 & 1.000 & 0.000 & 0.975 & 0.025 \\
\hline$u\left(w_{l}\right)=0.001$ & $u\left(w_{2}\right)=0.001$ & $u\left(w_{3}\right)=0.001$ & $u\left(w_{l}\right)=0.003$ & $u\left(w_{2}\right)=0.003$ & $u\left(w_{3}\right)=0.001$ \\
\hline
\end{tabular}

Standard uncertainties: $u(P)=5 \mathrm{kPa}, u(T)=0.05 \mathrm{~K}$. 
Table 4. Liquid-liquid equilibrium of the ternary system water (1) $+\left[\mathrm{C}_{6} \mathrm{mim}\right][\mathrm{OAc}]$ (2) $+n$-octane (3) at $323.15 \mathrm{~K}$ and $0.1 \mathrm{MPa}$.

\begin{tabular}{|c|c|c|c|c|c|}
\hline \multicolumn{3}{|c|}{ Upper phase } & \multicolumn{3}{|c|}{ Lower phase } \\
\hline$w_{1}$ & $w_{2}$ & $w_{3}$ & $w_{1}$ & $w_{2}$ & $w_{3}$ \\
\hline 0.000 & 0.000 & 1.000 & 1.000 & 0.000 & 0.000 \\
\hline 0.000 & 0.000 & 1.000 & 0.878 & 0.122 & 0.000 \\
\hline 0.000 & 0.000 & 1.000 & 0.786 & 0.214 & 0.000 \\
\hline 0.000 & 0.000 & 1.000 & 0.648 & 0.352 & 0.000 \\
\hline 0.000 & 0.000 & 1.000 & 0.515 & 0.485 & 0.000 \\
\hline 0.000 & 0.000 & 1.000 & 0.388 & 0.602 & 0.010 \\
\hline 0.000 & 0.000 & 1.000 & 0.243 & 0.748 & 0.009 \\
\hline 0.000 & 0.000 & 1.000 & 0.134 & 0.846 & 0.020 \\
\hline 0.000 & 0.000 & 1.000 & 0.035 & 0.944 & 0.021 \\
\hline 0.000 & 0.000 & 1.000 & 0.000 & 0.970 & 0.030 \\
\hline$=0.00$ & $\left.w_{2}\right)=0.001$ & $\left.y_{3}\right)=0.001$ & $\left.w_{l}\right)=0.003$ & $\left(w_{2}\right)=0.003$ & $\iota\left(w_{3}\right)=0.001$ \\
\hline
\end{tabular}

Standard uncertainties: $u(P)=5 \mathrm{kPa}, u(T)=0.05 \mathrm{~K}$. 
Table 5. Liquid-liquid equilibrium of the ternary system water (1) $+\left[\mathrm{C}_{6} \mathrm{mim}\right][\mathrm{OAc}](2)$ + toluene (3) at $298.15 \mathrm{~K}$ and $0.1 \mathrm{MPa}$.

\begin{tabular}{ccccccc}
\hline & Upper phase & & & \multicolumn{3}{c}{ Lower phase } \\
\cline { 1 - 2 } \cline { 5 - 6 } \cline { 5 - 6 } & $w_{2}$ & $w_{3}$ & & $w_{1}$ & $w_{2}$ & $w_{3}$ \\
\hline 0.000 & 0.000 & 1.000 & & 1.000 & 0.000 & 0.000 \\
0.000 & 0.000 & 1.000 & & 0.950 & 0.046 & 0.004 \\
0.000 & 0.000 & 1.000 & & 0.811 & 0.183 & 0.006 \\
0.000 & 0.000 & 1.000 & & 0.413 & 0.560 & 0.027 \\
0.000 & 0.000 & 1.000 & & 0.256 & 0.671 & 0.073 \\
0.000 & 0.000 & 1.000 & & 0.102 & 0.748 & 0.150 \\
0.000 & 0.000 & 1.000 & & 0.000 & 0.651 & 0.349 \\
\hline$u\left(w_{1}\right)=0.001$ & $u\left(w_{2}\right)=0.001$ & $u\left(w_{3}\right)=0.001$ & $u\left(w_{1}\right)=0.002$ & $u\left(w_{2}\right)=0.003$ & $u\left(w_{3}\right)=0.003$ \\
\hline$S$
\end{tabular}

Standard uncertainties: $u(P)=5 \mathrm{kPa}, u(T)=0.05 \mathrm{~K}$. 
Table 6. Liquid-liquid equilibrium of the ternary system water (1) $+\left[\mathrm{C}_{6} \mathrm{mim}\right][\mathrm{OAc}](2)$ + toluene (3) at $323.15 \mathrm{~K}$ and $0.1 \mathrm{MPa}$.

\begin{tabular}{ccccccc}
\hline & Upper phase & & & \multicolumn{3}{c}{ Lower phase } \\
\cline { 1 - 2 } \cline { 5 - 6 } \cline { 5 - 6 } & $w_{2}$ & $w_{3}$ & & $w_{1}$ & $w_{2}$ & $w_{3}$ \\
\hline 0.000 & 0.000 & 1.000 & & 1.000 & 0.000 & 0.000 \\
0.000 & 0.000 & 1.000 & & 0.849 & 0.148 & 0.003 \\
0.000 & 0.000 & 1.000 & & 0.706 & 0.289 & 0.005 \\
0.000 & 0.000 & 1.000 & & 0.378 & 0.589 & 0.033 \\
0.000 & 0.000 & 1.000 & & 0.247 & 0.684 & 0.069 \\
0.000 & 0.000 & 1.000 & & 0.105 & 0.737 & 0.158 \\
0.000 & 0.000 & 1.000 & & 0.000 & 0.643 & 0.357 \\
\hline$u\left(w_{1}\right)=0.001$ & $u\left(w_{2}\right)=0.001$ & $u\left(w_{3}\right)=0.001$ & $u\left(w_{1}\right)=0.002$ & $u\left(w_{2}\right)=0.003$ & $u\left(w_{3}\right)=0.003$ \\
\hline$S$
\end{tabular}

Standard uncertainties: $u(P)=5 \mathrm{kPa}, u(T)=0.05 \mathrm{~K}$ 
Table 7. Liquid-liquid equilibrium of the ternary system water (1) $+\left[\mathrm{C}_{6} \mathrm{mim}\right][\mathrm{OAc}](2)$ + cyclohexane (3) at $298.15 \mathrm{~K}$ and $0.1 \mathrm{MPa}$.

\begin{tabular}{|c|c|c|c|c|c|}
\hline \multicolumn{3}{|c|}{ Upper phase } & \multicolumn{3}{|c|}{ Lower phase } \\
\hline$w_{1}$ & $w_{2}$ & $w_{3}$ & $w_{1}$ & $w_{2}$ & $w_{3}$ \\
\hline 0.000 & 0.000 & 1.000 & 1.000 & 0.000 & 0.000 \\
\hline 0.000 & 0.000 & 1.000 & 0.892 & 0.108 & 0.000 \\
\hline 0.000 & 0.000 & 1.000 & 0.815 & 0.185 & 0.000 \\
\hline 0.000 & 0.000 & 1.000 & 0.679 & 0.318 & 0.003 \\
\hline 0.000 & 0.000 & 1.000 & 0.556 & 0.440 & 0.004 \\
\hline 0.000 & 0.000 & 1.000 & 0.428 & 0.564 & 0.008 \\
\hline 0.000 & 0.000 & 1.000 & 0.365 & 0.624 & 0.011 \\
\hline 0.000 & 0.000 & 1.000 & 0.228 & 0.750 & 0.022 \\
\hline 0.000 & 0.000 & 1.000 & 0.108 & 0.850 & 0.042 \\
\hline 0.000 & 0.000 & 1.000 & 0.000 & 0.954 & 0.046 \\
\hline$u\left(w_{l}\right)=0.001$ & $u\left(w_{2}\right)=0.001$ & $u\left(w_{3}\right)=0.001$ & $u\left(w_{I}\right)=0.003$ & $u\left(w_{2}\right)=0.003$ & $u\left(w_{3}\right)=0.001$ \\
\hline
\end{tabular}


Table 8. Liquid-liquid equilibrium of the ternary system water (1) $+\left[\mathrm{C}_{6} \mathrm{mim}\right][\mathrm{OAc}](2)$ + cyclohexane (3) at $323.15 \mathrm{~K}$ and $0.1 \mathrm{MPa}$.

\begin{tabular}{|c|c|c|c|c|c|}
\hline \multicolumn{3}{|c|}{ Upper phase } & \multicolumn{3}{|c|}{ Lower phase } \\
\hline$w_{1}$ & $w_{2}$ & $w_{3}$ & $w_{1}$ & $w_{2}$ & $w_{3}$ \\
\hline 0.000 & 0.000 & 1.000 & 1.000 & 0.000 & 0.000 \\
\hline 0.000 & 0.000 & 1.000 & 0.886 & 0.114 & 0.000 \\
\hline 0.000 & 0.000 & 1.000 & 0.805 & 0.195 & 0.000 \\
\hline 0.000 & 0.000 & 1.000 & 0.645 & 0.351 & 0.004 \\
\hline 0.000 & 0.000 & 1.000 & 0.514 & 0.480 & 0.006 \\
\hline 0.000 & 0.000 & 1.000 & 0.428 & 0.563 & 0.009 \\
\hline 0.000 & 0.000 & 1.000 & 0.354 & 0.633 & 0.013 \\
\hline 0.000 & 0.000 & 1.000 & 0.234 & 0.741 & 0.025 \\
\hline 0.000 & 0.000 & 1.000 & 0.114 & 0.841 & 0.045 \\
\hline 0.000 & 0.000 & 1.000 & 0.000 & 0.953 & 0.047 \\
\hline$u\left(w_{l}\right)=0.001$ & $u\left(w_{2}\right)=0.001$ & $u\left(w_{3}\right)=0.001$ & $u\left(w_{l}\right)=0.003$ & $u\left(w_{2}\right)=0.003$ & $u\left(w_{3}\right)=0.001$ \\
\hline
\end{tabular}

Standard uncertainties: $u(P)=5 \mathrm{kPa}, u(T)=0.05 \mathrm{~K}$ 
Table 9. Binary interaction parameters and residual function for the correlations of the ternary system water $(1)+\left[\mathrm{C}_{6} \mathrm{mim}\right][\mathrm{OAc}](2)+n$-octane (3).

\begin{tabular}{|c|c|c|c|c|c|}
\hline $\begin{array}{l}\text { Temperature } \\
(\mathrm{K})\end{array}$ & \multicolumn{4}{|c|}{ Parameters (alpha $=0.2$ ) } & Deviation \\
\hline \multirow{3}{*}{$298.15 \mathrm{~K}$} & $u_{12}(\mathrm{~J} / \mathrm{mol})$ & -1008.0 & $u_{21}(\mathrm{~J} / \mathrm{mol})$ & -1147.3 & \multirow{3}{*}{$\mathrm{F}=0.17$} \\
\hline & $u_{13}(\mathrm{~J} / \mathrm{mol})$ & 10965 & $u_{31}(\mathrm{~J} / \mathrm{mol})$ & 11229 & \\
\hline & $u_{23}(\mathrm{~J} / \mathrm{mol})$ & 3591.7 & $u_{32}(\mathrm{~J} / \mathrm{mol})$ & 11071 & \\
\hline \multirow{3}{*}{$323.15 \mathrm{~K}$} & $u_{12}(\mathrm{~J} / \mathrm{mol})$ & -1373.9 & $u_{21}(\mathrm{~J} / \mathrm{mol})$ & -1227.8 & \multirow{3}{*}{$\mathrm{F}=0.18$} \\
\hline & $u_{13}(\mathrm{~J} / \mathrm{mol})$ & 11406 & $u_{31}(\mathrm{~J} / \mathrm{mol})$ & 12210 & \\
\hline & $u_{23}(\mathrm{~J} / \mathrm{mol})$ & 3437.3 & $u_{32}(\mathrm{~J} / \mathrm{mol})$ & 12384 & \\
\hline \multirow{3}{*}{ Both } & $u_{12}(\mathrm{~J} / \mathrm{mol})$ & -1488.3 & $u_{21}(\mathrm{~J} / \mathrm{mol})$ & -1397.0 & \multirow{3}{*}{$\mathrm{F}=0.30$} \\
\hline & $u_{13}(\mathrm{~J} / \mathrm{mol})$ & 11602 & $u_{31}(\mathrm{~J} / \mathrm{mol})$ & 12566 & \\
\hline & $u_{23}(\mathrm{~J} / \mathrm{mol})$ & 3475.6 & $u_{32}(\mathrm{~J} / \mathrm{mol})$ & 12557 & \\
\hline
\end{tabular}

Table 10. Binary interaction parameters and residual function for the correlations of the ternary system water (1) $+\left[\mathrm{C}_{6}\right.$ mim $][\mathrm{OAc}](2)+$ toluene (3).

\begin{tabular}{|c|c|c|c|c|c|}
\hline Temperature & \multicolumn{4}{|c|}{ Parameters (alpha $=0.3$ ) } & Deviation \\
\hline \multirow{3}{*}{$298.15 \mathrm{~K}$} & $u_{12}(\mathrm{~J} / \mathrm{mol})$ & -5438.8 & $u_{21}(\mathrm{~J} / \mathrm{mol})$ & -6698.9 & \multirow{3}{*}{$\mathrm{F}=0.16$} \\
\hline & $u_{13}(\mathrm{~J} / \mathrm{mol})$ & 13212 & $u_{31}(\mathrm{~J} / \mathrm{mol})$ & 14993 & \\
\hline & $u_{23}(\mathrm{~J} / \mathrm{mol})$ & 3812.2 & $u_{32}(\mathrm{~J} / \mathrm{mol})$ & 11012 & \\
\hline \multirow{3}{*}{$323.15 \mathrm{~K}$} & $u_{12}(\mathrm{~J} / \mathrm{mol})$ & -6538.6 & $u_{21}(\mathrm{~J} / \mathrm{mol})$ & -7918.3 & \multirow{3}{*}{$\mathrm{F}=0.18$} \\
\hline & $u_{13}(\mathrm{~J} / \mathrm{mol})$ & 13843 & $u_{31}(\mathrm{~J} / \mathrm{mol})$ & 16503 & \\
\hline & $u_{23}(\mathrm{~J} / \mathrm{mol})$ & 4066.6 & $u_{32}(\mathrm{~J} / \mathrm{mol})$ & 11820 & \\
\hline \multirow{3}{*}{ Both } & $u_{12}(\mathrm{~J} / \mathrm{mol})$ & -6222.9 & $u_{21}(\mathrm{~J} / \mathrm{mol})$ & -7376.2 & \multirow{3}{*}{$\mathrm{F}=0.26$} \\
\hline & $u_{13}(\mathrm{~J} / \mathrm{mol})$ & 14421 & $u_{31}(\mathrm{~J} / \mathrm{mol})$ & 16961 & \\
\hline & $u_{23}(\mathrm{~J} / \mathrm{mol})$ & 4084.4 & $u_{32}(\mathrm{~J} / \mathrm{mol})$ & 12364 & \\
\hline
\end{tabular}


Table 11. Binary interaction parameters and residual function for the correlations of the ternary system water $(1)+\left[\mathrm{C}_{6} \mathrm{mim}\right][\mathrm{OAc}](2)+$ cyclohexane (3).

\begin{tabular}{|c|c|c|c|c|c|}
\hline Temperature & \multicolumn{4}{|c|}{ Parameters (alpha $=0.2$ ) } & Deviation \\
\hline \multirow{3}{*}{$298.15 \mathrm{~K}$} & $u_{12}(\mathrm{~J} / \mathrm{mol})$ & -1769.5 & $u_{21}(\mathrm{~J} / \mathrm{mol})$ & -1644.5 & \multirow{3}{*}{$\mathrm{F}=0.24$} \\
\hline & $u_{13}(\mathrm{~J} / \mathrm{mol})$ & 9539.9 & $u_{31}(\mathrm{~J} / \mathrm{mol})$ & 11470 & \\
\hline & $u_{23}(\mathrm{~J} / \mathrm{mol})$ & -3934.1 & $u_{32}(\mathrm{~J} / \mathrm{mol})$ & 16832 & \\
\hline \multirow{3}{*}{$323.15 \mathrm{~K}$} & $u_{12}(\mathrm{~J} / \mathrm{mol})$ & -2917.9 & $u_{21}(\mathrm{~J} / \mathrm{mol})$ & -451.50 & \multirow{3}{*}{$\mathrm{F}=0.21$} \\
\hline & $u_{13}(\mathrm{~J} / \mathrm{mol})$ & 10858 & $u_{31}(\mathrm{~J} / \mathrm{mol})$ & 11865 & \\
\hline & $u_{23}(\mathrm{~J} / \mathrm{mol})$ & -4412.6 & $u_{32}(\mathrm{~J} / \mathrm{mol})$ & 18631 & \\
\hline \multirow{3}{*}{ Both } & $u_{12}(\mathrm{~J} / \mathrm{mol})$ & -7180.5 & $u_{21}(\mathrm{~J} / \mathrm{mol})$ & -694.70 & \multirow{3}{*}{$\mathrm{F}=0.68$} \\
\hline & $u_{13}(\mathrm{~J} / \mathrm{mol})$ & 10176 & $u_{31}(\mathrm{~J} / \mathrm{mol})$ & 12068 & \\
\hline & $u_{23}(\mathrm{~J} / \mathrm{mol})$ & -4063.3 & $u_{32}(\mathrm{~J} / \mathrm{mol})$ & 16720 & \\
\hline
\end{tabular}

Table 12. Binary interaction parameters and residual function for the simultaneous correlations of all the ternary systems.

\begin{tabular}{|c|c|c|c|c|}
\hline \multicolumn{4}{|c|}{ Parameters (alpha $=0.2)$} & \multirow[t]{2}{*}{ Deviation } \\
\hline$u W-I L(\mathrm{~J} / \mathrm{mol})$ & -12595 & $u I L-W(\mathrm{~J} / \mathrm{mol})$ & 478.20 & \\
\hline$u_{W-O}(\mathrm{~J} / \mathrm{mol})$ & 11699 & $u_{O-W}(\mathrm{~J} / \mathrm{mol})$ & 12386 & \\
\hline$u_{I L-O}(\mathrm{~J} / \mathrm{mol})$ & 3465.0 & UO-IL $(\mathrm{J} / \mathrm{mol})$ & 12545 & \\
\hline$u_{W-T}(\mathrm{~J} / \mathrm{mol})$ & 9082.8 & $u_{T-W}(\mathrm{~J} / \mathrm{mol})$ & 12411 & 1.74 \\
\hline$u_{I L-T}(\mathrm{~J} / \mathrm{mol})$ & 1600.2 & $u_{T-I L}(\mathrm{~J} / \mathrm{mol})$ & 15744 & \\
\hline$u_{W-C}(\mathrm{~J} / \mathrm{mol})$ & 10417 & $u_{C-W}(\mathrm{~J} / \mathrm{mol})$ & 12628 & \\
\hline$u_{I L-C}(\mathrm{~J} / \mathrm{mol})$ & -3956.6 & $u_{C-I L}(\mathrm{~J} / \mathrm{mol})$ & 16117 & \\
\hline
\end{tabular}

$W$ : Water; $I L$ : Ionic Liquid; $O: n$-Octane; $T$ : Toluene; $C$ : Cyclohexane 


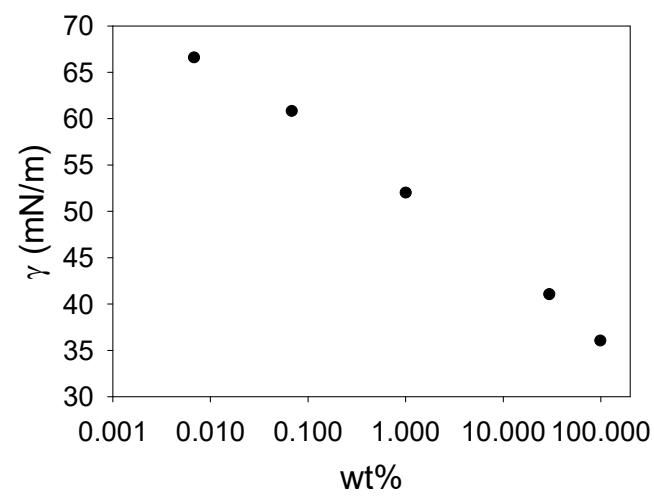

Figure 1: Surface tension as function of $\left[\mathrm{C}_{6} \mathrm{mim}\right][\mathrm{OAc}]$ concentration in aqueous solution. 


\section{$\left[\mathrm{C}_{6} \mathrm{mim}\right][\mathrm{OAc}]$}

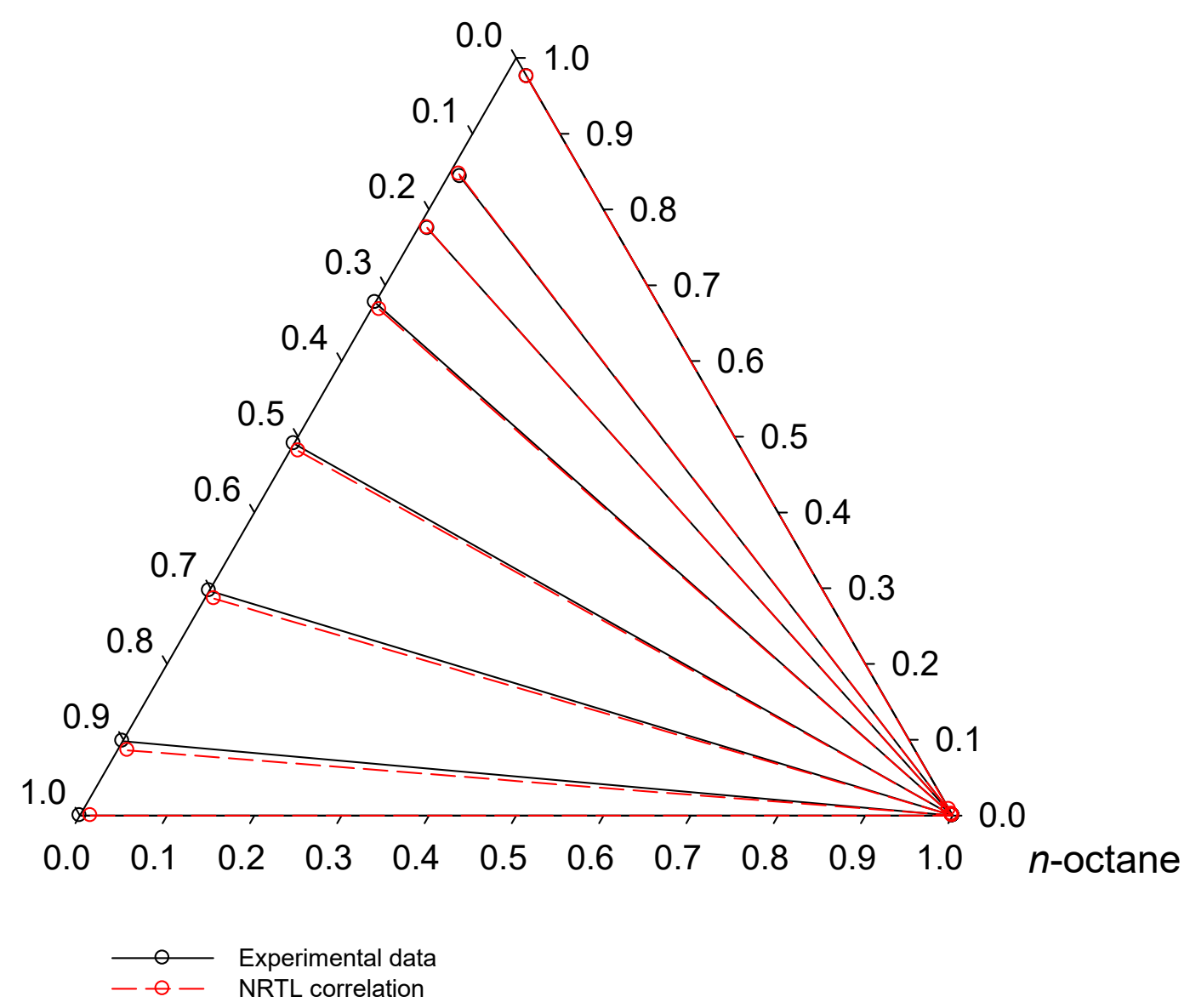

Figure 2: LLE of the ternary system water $+\left[\mathrm{C}_{6} \mathrm{mim}\right][\mathrm{OAc}]+n$-octane at $298.15 \mathrm{~K}$ and $0.1 \mathrm{MPa}$. 


\section{$\left[\mathrm{C}_{6} \operatorname{mim}\right][\mathrm{OAc}]$}

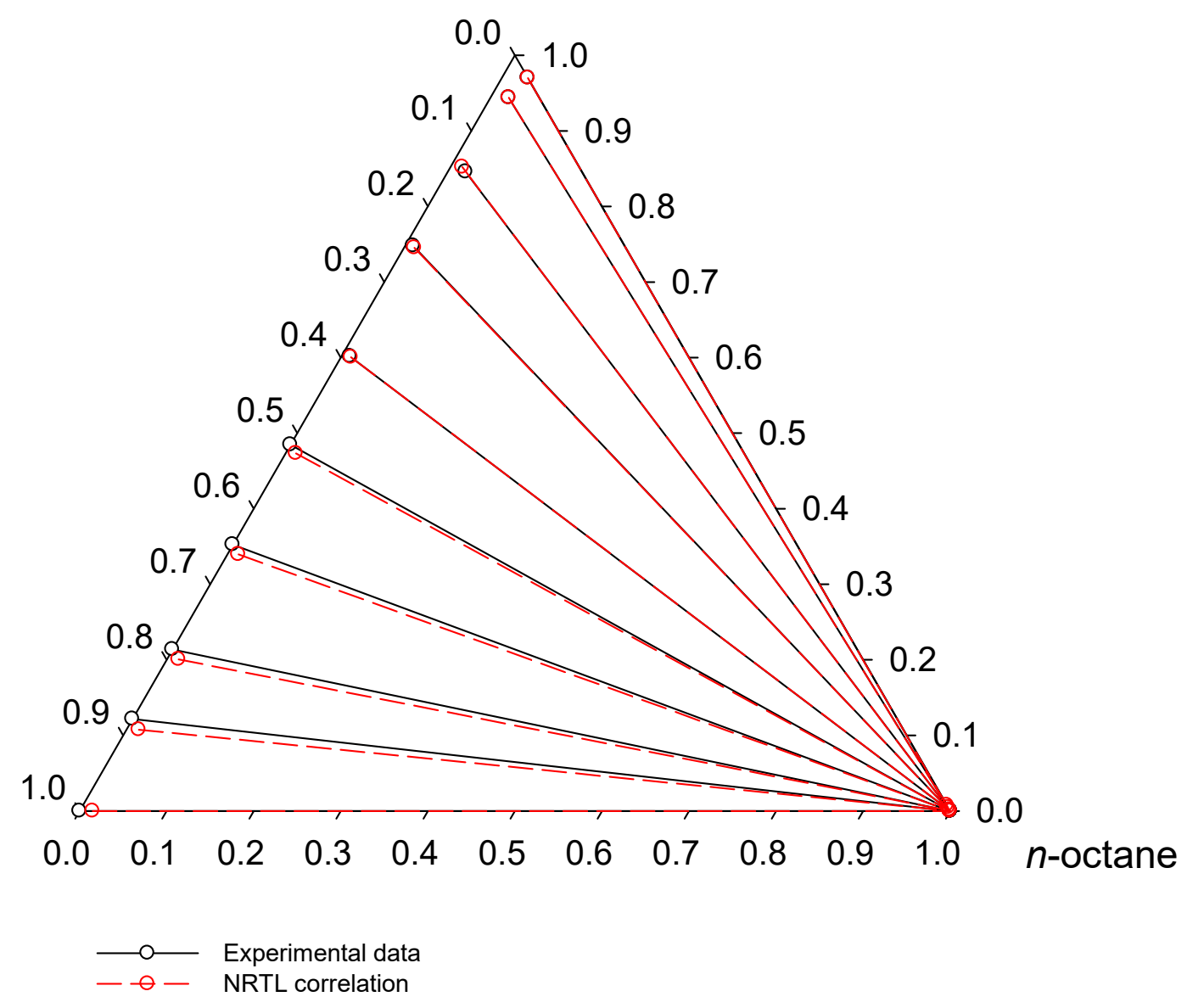

Figure 3: LLE of the ternary system water $+\left[\mathrm{C}_{6} \mathrm{mim}\right][\mathrm{OAc}]+n$-octane at $323.15 \mathrm{~K}$ and $0.1 \mathrm{MPa}$. 
$\left[\mathrm{C}_{6} \mathrm{mim}\right][\mathrm{OAc}]$

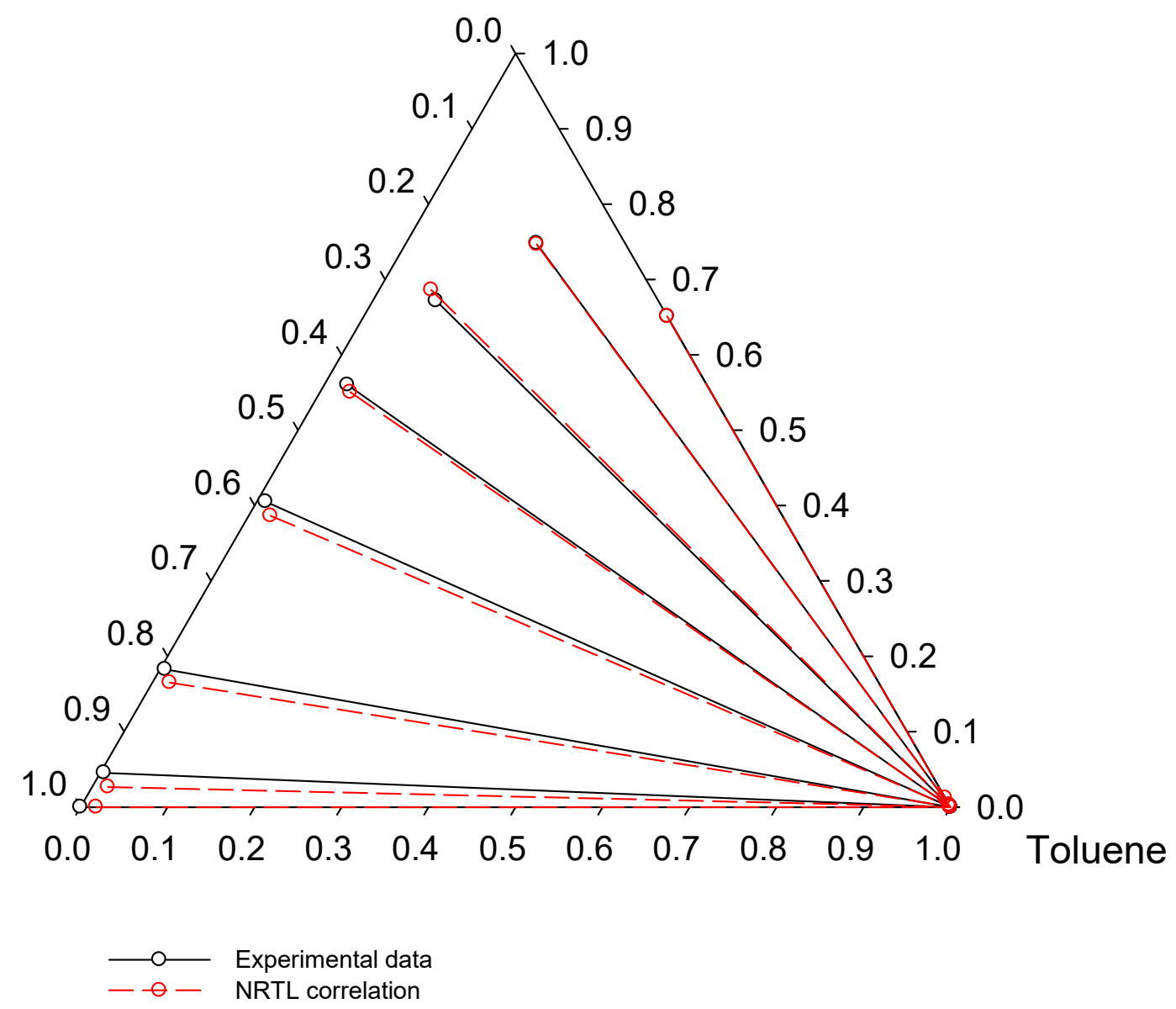

Figure 4: LLE of the ternary system water $+\left[\mathrm{C}_{6} \mathrm{mim}\right][\mathrm{OAc}]+$ toluene at $298.15 \mathrm{~K}$ and $0.1 \mathrm{MPa}$. 
$\left[\mathrm{C}_{6} \mathrm{mim}\right][\mathrm{OAc}]$

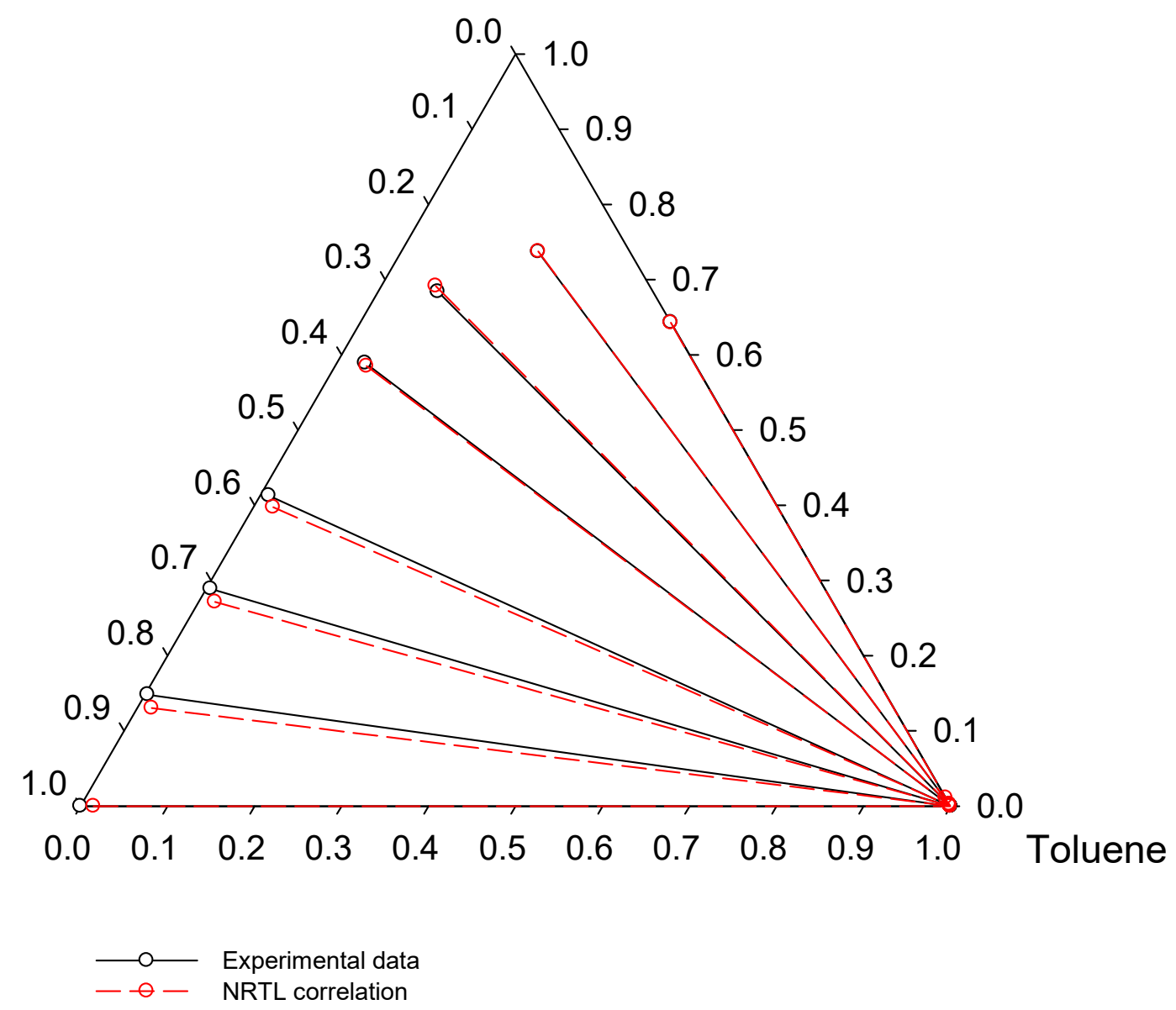

Figure 5: LLE of the ternary system water $+\left[\mathrm{C}_{6} \mathrm{mim}\right][\mathrm{OAc}]+$ toluene at $323.15 \mathrm{~K}$ and $0.1 \mathrm{MPa}$. 


\section{$\left[\mathrm{C}_{6} \operatorname{mim}\right][\mathrm{OAc}]$}

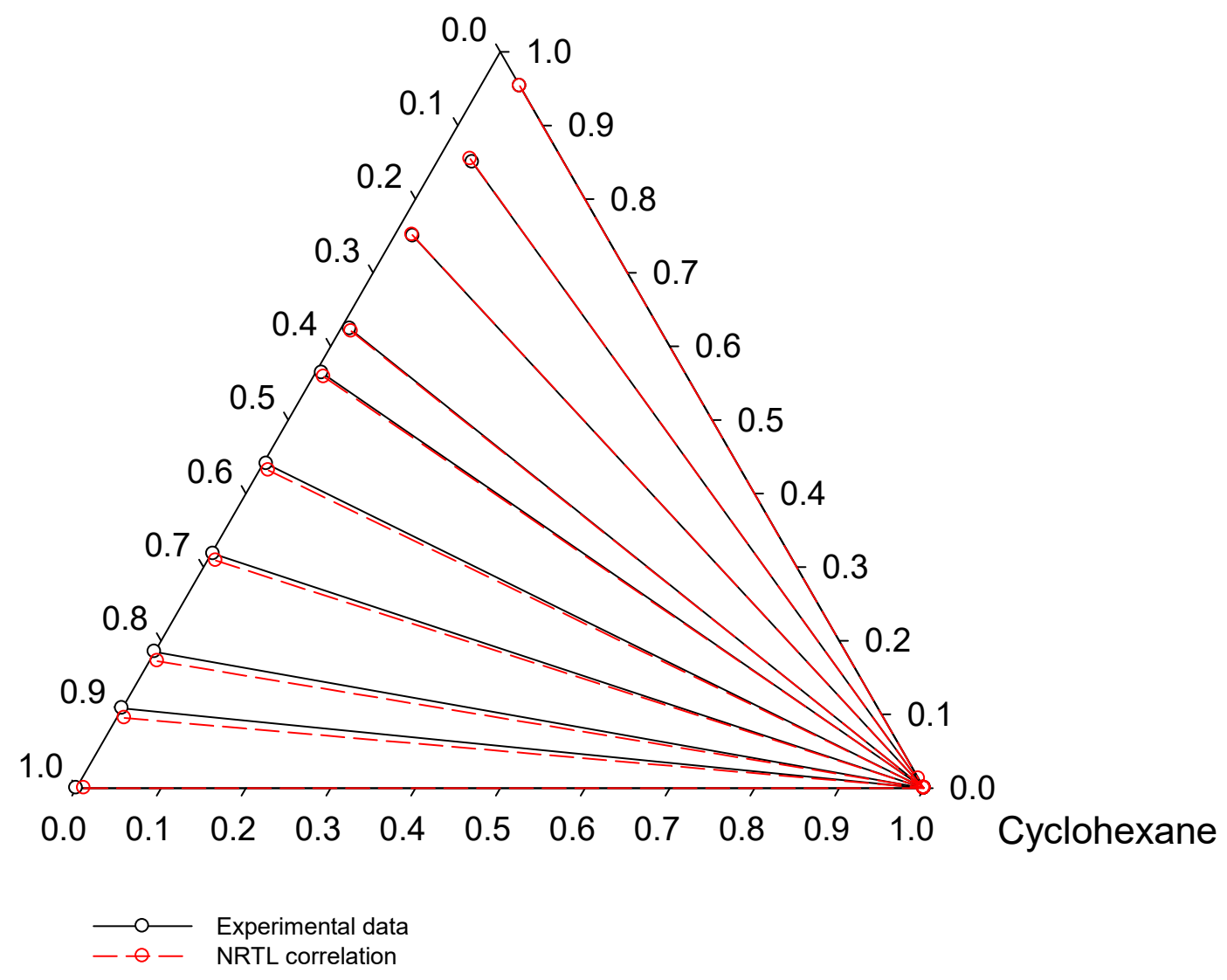

Figure 6: LLE of the ternary system water $+\left[\mathrm{C}_{6} \mathrm{mim}\right][\mathrm{OAc}]+$ cyclohexane at $298.15 \mathrm{~K}$ and 0.1 MPa. 


\section{$\left[\mathrm{C}_{6} \operatorname{mim}\right][\mathrm{OAc}]$}

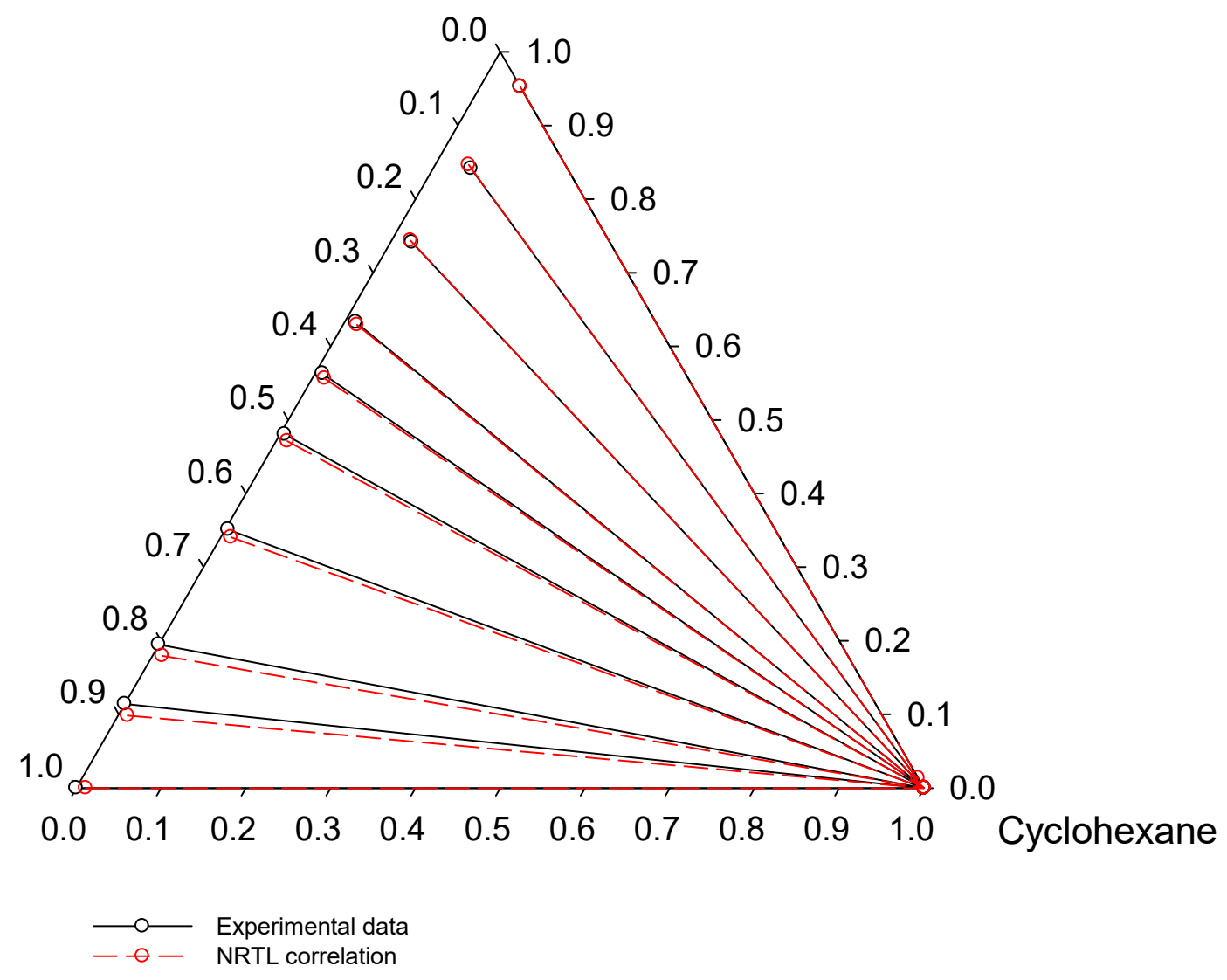

Figure 7: LLE of the ternary system water $+\left[\mathrm{C}_{6} \mathrm{mim}\right][\mathrm{OAc}]+$ cyclohexane at $323.15 \mathrm{~K}$ and 0.1 MPa. 

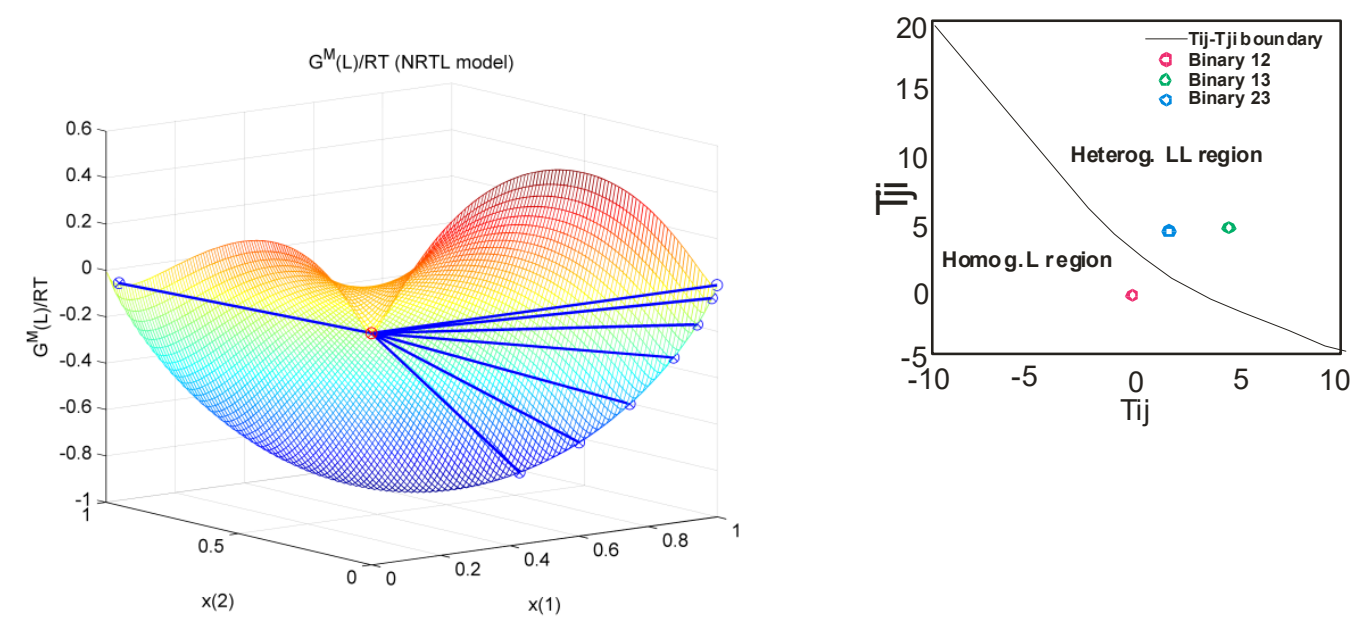

Water (1) $+[$ Comim $][\mathrm{OAc}](2)+n$-octane (3) at $298.15 \mathrm{~K}$
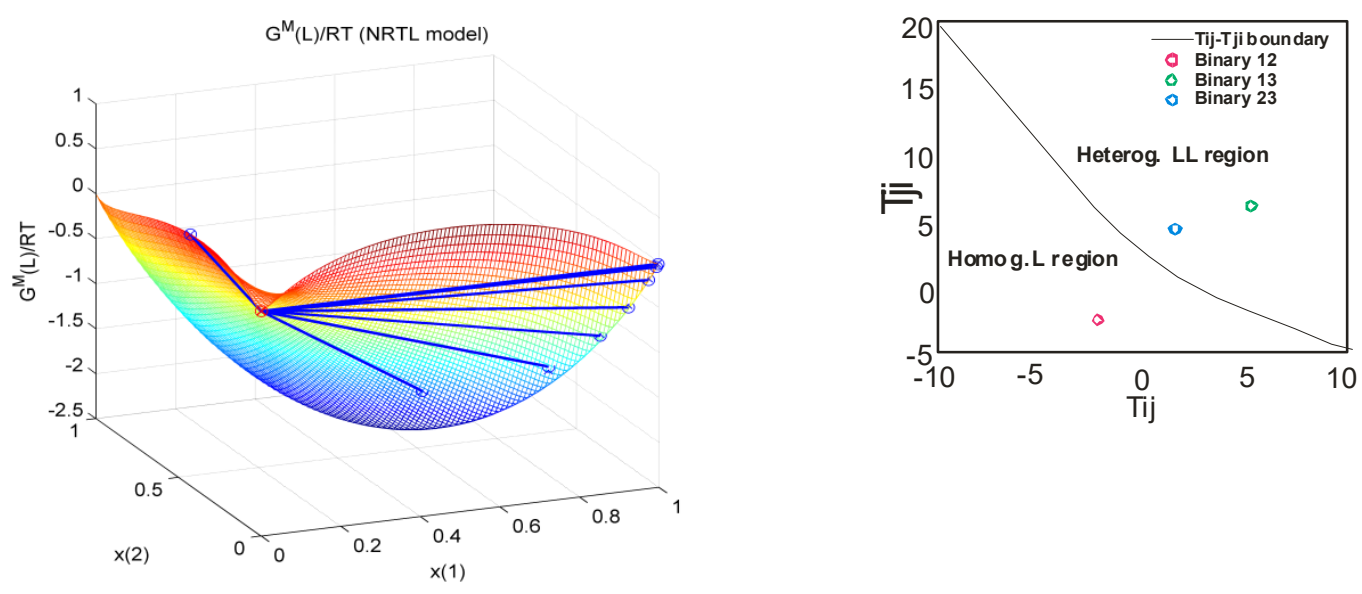

Water (1) $+\left[\mathrm{C}_{6} \mathrm{mim}\right][\mathrm{OAc}](2)+$ toluene (3) at $298.15 \mathrm{~K}$
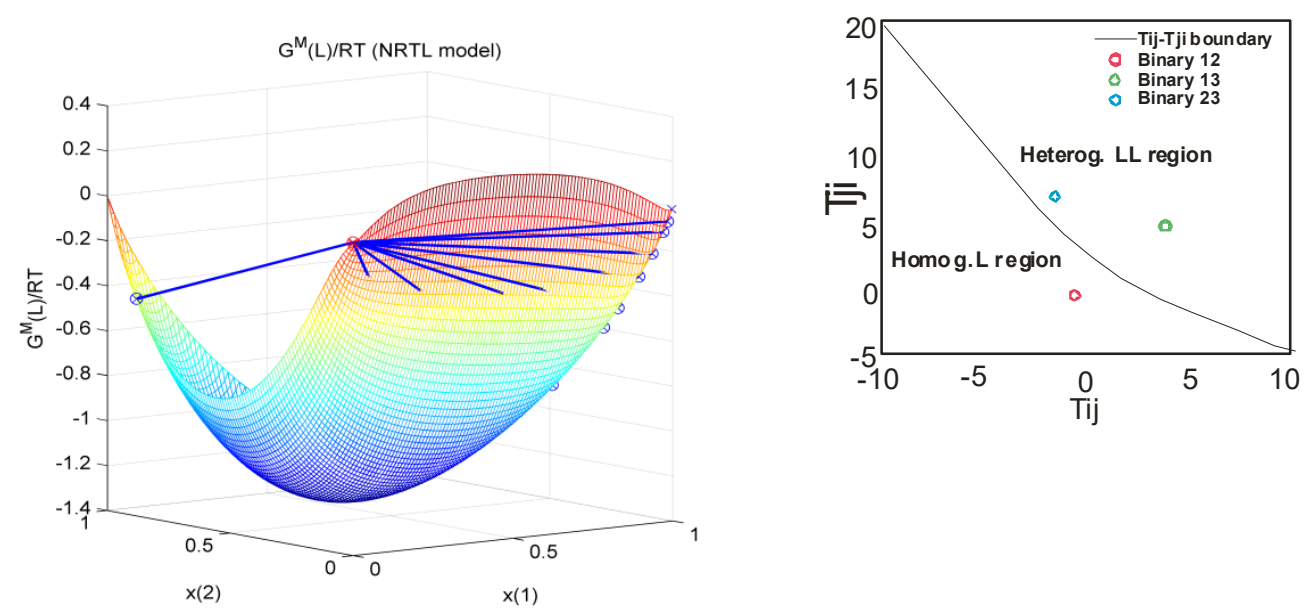

Water (1) $+\left[\mathrm{C}_{6} \mathrm{mim}\right][\mathrm{OAc}](2)+$ cyclohexane (3) at $298.15 \mathrm{~K}$

Figure $8 . \mathrm{G}^{\mathrm{M}}(\mathrm{L}) / \mathrm{RT}$ and miscibility boundary for ternary systems at $298.15 \mathrm{~K}$. 